\title{
Analisis Penyebaran Penularan Virus Corona Di Provinsi Jawa Barat Menggunakan Algoritma K-Means Clustering
}

\author{
Darmansah* $^{* 1}$, Ilham Chairuddin ${ }^{2}$, Ringga Sentagi Asa ${ }^{3}$ \\ ${ }^{1}$ Institut Teknologi Telkom Purwokerto; Jl. DI. Panjaitan No.128 Purwokerto, \\ Telp 0281-641629 \\ ${ }^{2,3}$ Sekolah Tinggi Teknologi Pekanbaru; Jl. Dirgantara No.4 Soekarno Hatta Pekanbaru \\ e-mail:*12darmansah@ittelkom-pwt.ac.id, ${ }^{2}$ ilham.chairuddin@gmail.com, \\ ${ }^{3}$ sentagiasa@gmail.com
}

\begin{abstract}
Abstrak
Virus corona atau covid-19 saat ini telah menyebar di negara negara yang ada di dunia. Virus ini ditemukan peratama kalinya di negeri tirai bamboo (China) dan hari ini telah menyebar sampai ke negara negara didunia tidak terkecuali negara Indonesia. Semua daerah yang ada di Indonesia saat ini telah tertular sejak maret 2019 sampai hari ini. Jawa barat adalah salah satu daerah yang tertular virus corona di Indonesia. Terdapat semua kabupaten kota di jawa barat dilaporkan telah terpapar virus ini. Supaya pemerintah mudah dalam mengambil kebijakan untuk mencegah penularan virus ini, maka untuk itu diperlukan penelitian yang bisa mengelompokan persebaran virus covid-19 guna menekan laju penularan di daerah tersebut. Untuk memudahkan peneliti dalam pengelompokan penularan maka disini peneliti membagi ke dalam 3 kelompok yaitu rendah (CO), Sedang (C1) dan Tinggi (C2). Dalam penelitian ini menggunakan algoritma $K$-Means Clustering dan pengolahan data peneliti menggunakan software rapidminer Studio 7.6. Dari hasil penelitian ditemukan bahwa ada 19 kabupaten/kota masuk kedalam CO, 4 kabupaten/kota kedalam C1 dan 4 kabupaten/kota lagi kedalam C2.
\end{abstract}

Kata kunci- Analisis, Covid-19, Datamining, K-Means dan Clustering.

\begin{abstract}
The corona virus or covid-19 has now spread in countries around the world. This virus was first discovered abroad (China) and today it has spread to countries in the world, without Indonesia. All regions in Indonesia have been infected since the 2019 market until today. West Java is one of the areas infected with the corona virus in Indonesia. There are all urban districts in West Java that have been reported to have been exposed to this virus. In order for the government to easily take policies to prevent the transmission of this virus, it is necessary to conduct research that can classify the spread of the Covid-19 virus in order to suppress the rate of transmission in the area. To make it easier for researchers to group distribution, here the researchers divide into 3 groups, namely Low (CO), Medium (C1) and High (C2). In this study using the K-Means Clustering algorithm and data processing researchers using rapidminer Studio 7.6 software. From the results of the study, it was found that there were 19 districts/cities included in CO, 4 districts/cities entered into $\mathrm{Cl}$ and 4 districts/cities entered into $\mathrm{C2}$.
\end{abstract}

Keywords-Analysis, Covid-19, Datamining, K-Means and Clustering. 


\section{PENDAHULUAN}

$\mathrm{V}$ irus corona atau covid-19 menular dengan sangat cepat di dunia. Saat sekarang ini virus korona telah menyerang hamper seluruh negara dibelahan dunia tidak terkecuali negara indonesia [1][2]. Virus corona adalah virus yang pertama kali muncul di china pada desember 2019. Bagi penderita virus ini akan mengalami kesulitan untuk bernafas. Virus ini bisa berkembang kearah yang lebih serius jika virus ini tertular pada masyarakat yang sudah lanjut usia dan kepada masyarakat yang sudah mempunyai penyakit bawaan [3]. Virus corona menyebabkan pandemi secara dunia. Gejala utama yang di rasakan bagi penderitanya dalah batuk, demam dan sulit bernafas [4].

Virus corona merupakan kumpulan virus dari subfamili Orthocronavirinae. Virus ini tidak hanya bisa menimbulkan penyakit kepada manusia tetapi juga pada hewan. Ketika virus ini tertular kepada manusia maka sipenderita akan mengalami inveksi pada saluran pernafasan seprti flu [5]. Ketika virus ini mulai melanda Indonesia, pemerintah telah melakukan cara untuk mencegah virus ini menular dengan cepat di Indonesia. [6]. Tidak hanya pemerintah yang telah melakukan berbagai cara untuk menekan laju penularan, tetapi semua pihak telah mencoba memberikan cara dan solusi agar penuluran virus ini bisa terhenti, karena virus ini makin hari makin banyak masyarakat yang terpapar, hal ini dibuktikan dengan terus meningkatnya kasus penularan setiap harinya [7].

Salah satu daerah yang saat ini kasus pesebaran penuluran virus corona tinggi di indonesia yaitu provinsi Jawa Barat (Prov Jabar). Terdapat 27 kabupaten dan kota di daerah ini dan semuanya itu sudah tertular virus corona. Pada penelitian ini, peneliti mengelompokan penuluran kasus virus corona di jawa barat kedalam 3 kelompok. Dimana diantara tiga kelompok ini terdiri dari kelompok penuluran rendah $(\mathrm{C} 0)$, sedang $(\mathrm{C} 1)$ dan tinggi $(\mathrm{C} 2)$. Hasil dari penelitian ini diharapkan bisa menjadi solusi untuk menekan lajur penulran virus corona dengan telah tekelompok kelompoknya daerah tersebut. Dalam penelitian ini, peneliti menggunakan metode datamining dengan memakai algoritma K-Means Clustering. Kemudian dalam pengolahan data peneliti menggunakan aplikasi rapidminer studio 7.6.

Data mining diperlukan guna dalam memudahkan untuk pengambilan keputusan ketika menggunakan jumlah data yang sangat banyak [8]. Selain itu data mining ialah sebuah cara pengolahan data yang dapat dengan mudah menemukan pola yang tersimpan dalam sebuah basis data yang komplek [9]. Data mining adalah sebuah cara yang bisa digunakan dalam banyak bidang ilmu guna untuk mencari sebuah pengetahuan didalam sebuah data yang ukurannya besar [10]. Algoritma K-Means adalah sebuah algoritma yang mengelompokan data berdasarkan titik centroid terdekat. Algoritma ini memaksimalkan kesamaan sebuah data [11]. Algoritma $K$-Means bisa dikatakan sebagai clustering non hirarki yang mengelompokan data kedalam satu atau lebih kelompok yang memiliki karakteristik yang sama [12]. Diantara beberapa teknik clustering yang terdapat pada metode datamining, yang paling popular dan sering digunakan adalah $K$-Means Clustering. Hal ini disebakan oleh kemampuan algoritma ini dalam mengelompokan data dengan jumlah yang sangat besar [13].

Selain itu Clustering ialah sebuah proses pengelompokan sebuah objek berdasarkan kepada informasi yang mempunyai hubungan dan kemiripan antar data tersebut kedalam kelas kelas yang sama [8]. Clustering ialah klasterisasi sebuah data dan membagi pola data menjadi beberapa kelompok sehingga membentuk sebuah pola yang sama dengan kelompok yang sama [14].[15]. [16]. [17] [18]. 


\section{METODE PENELITIAN}

Pada tahapan ini peneliti membuat cara atau metodologi penelitian yang digunakan. Metode ini digunakan untuk menjelaskan tahapan tahapan dalam penelitian yang dilakukan. Adapun metode penelitian dapat dilihat pada gambar dibawah ini:

\section{Metode Penelitian}

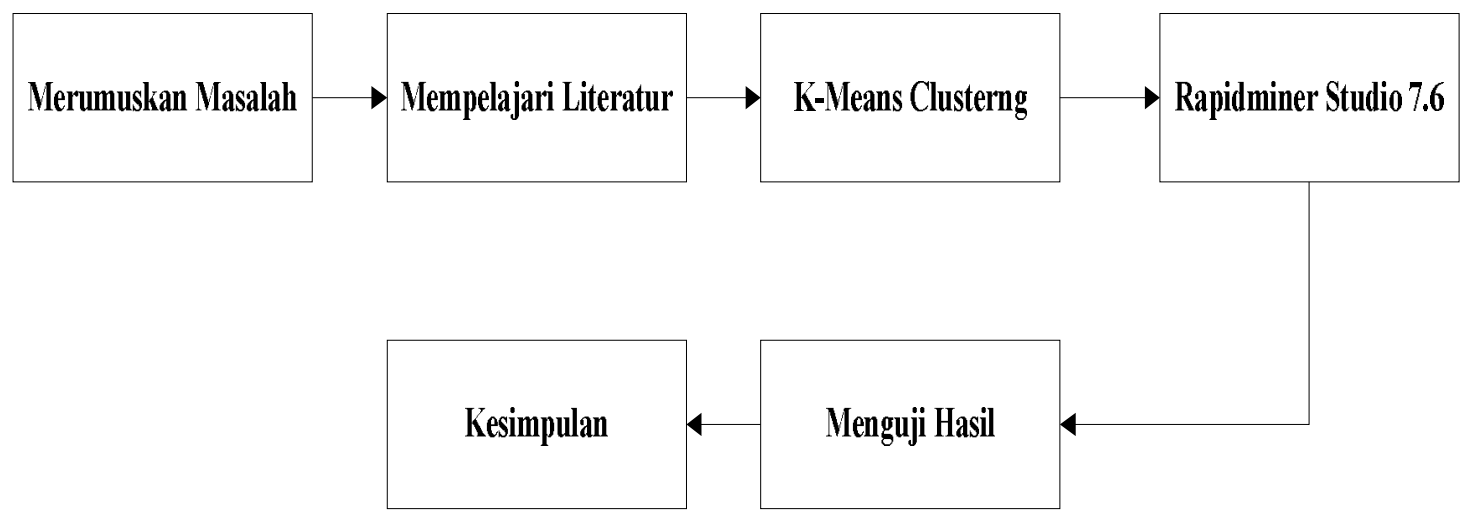

Gambar 1. Metode Penelitian

Untuk menjelaskan masing masing dari tahapan metode penelitian diatas dapat dilihat pada uruaian yang peneliti buat dibawah ini:

\subsection{Perumusan Masalah}

Tahapan ini peneliti merumuskan masalah yang akan diteliti. Pada tahapan ini peneliti menentukan objek dari penelitian, hal ini berfungsi untuk memudahkan dalam mencari data dan sumber sumber yang diperlukan dalam penelitian ini. Setelah mengetahui masalah apa yang akan diselesaikan maka peneliti bisa menemukan solusi yang cepat guna menyelesaikan masalah. Adapaun data yang di ambil dan dijadikan objek penelitian ini adalah data pesebaran virus corona di propinsi jawa barat yang diperoleh dari data Dinas Kesehatan Provinsi Jawa Barat pada tahun 2021.

\subsection{Studi Literatur}

Setelah peneliti mendapatkan objek dan data penelitian makan tahapan selanjutnya adalah mempelajari sumber sumber yang bisa dijadikan referensi dalam penelitian ini. Sumber sumber yang peneliti gunakan sebagai referensi yaitu buku buku, jurnal yang berkaitan dengan metode yang peneliti pakai. Hal ini dilakukan guna untuk memperkuat pengetahuan serta membuat penelitian ini mendapatkan hasil yang baik sesuai harapan.

\subsection{Algoritma K-Means}

Setelah melakukan perumusan masalah dan studi literature, maka peneliti melakukan pengolahan data menggunakan algoritma K-Means Clustering. Adapaun data yang diolah adalah data yang sudah di dapatkan dari Dinas Kesehatan Provinsi Jawa Barat. 


\subsection{Rapidmine Studio 7.6}

Untuk memudahkan dan hasil penelitian sesuai yang diharapkan disini peneliti menggunakan tools rapidminer studio 7.6. Tools ini dapat memudahkan dalam mengolah data yang jumlahnya besar.

\subsection{Menguji Hasil}

Pada bagian ini peneliti melakukan pengujian hasil. Ketika sudah tidak terdapat kesalahan pada perhitungan data menggunakan algoritma $\mathrm{K}$-Means Clustering dengan menggunakan tools rapidminer studio 7.6. maka selanjutnya hasil penelitian ini bisa dipublikasikan.

\subsection{Kesimpulan}

Setelah melakukan serangkaian tahapan yang sudah dijelaskan sebelumnya, maka pada bagian ini adalah peneliti melakukan penarikan sebuah kesimpulan. Yang mana nantinya kesimpulan ini adalah hasil sebuah penelitian ini yang bisa dijadikan sebagai salah satu indikator untuk mengambil kebijakan guna menekan pesebaran penularan kasus virus corona di Jawa Barat berdasarkan tingkat pesebaran yang ada di kabupaten kota se Jawa Barat.

\section{HASIL DAN PEMBAHASAN}

\subsection{Model Pemprosesan}

Adapun tahapan tahapan dalam penyelesaikan masalah menggunakan K-Means Clustering yaitu dimulai dari menentukan jumlah cluster atau kelompok, menentukan jarak pusat cluster awal, menentukan jarak euclidean, menentukan letak cluster, menentukan pusat cluster baru dan yang terakhir membandingkan hasil pengujian. Jika letak cluster tidak berubah, maka prose pemprosesan dianggap selesai. Adapun gambar dari model pemprosesan dapat dilihat seperti gambar 2 dibawah ini:

\section{Model Pemprosesan Algoritma K-Means Clustering}

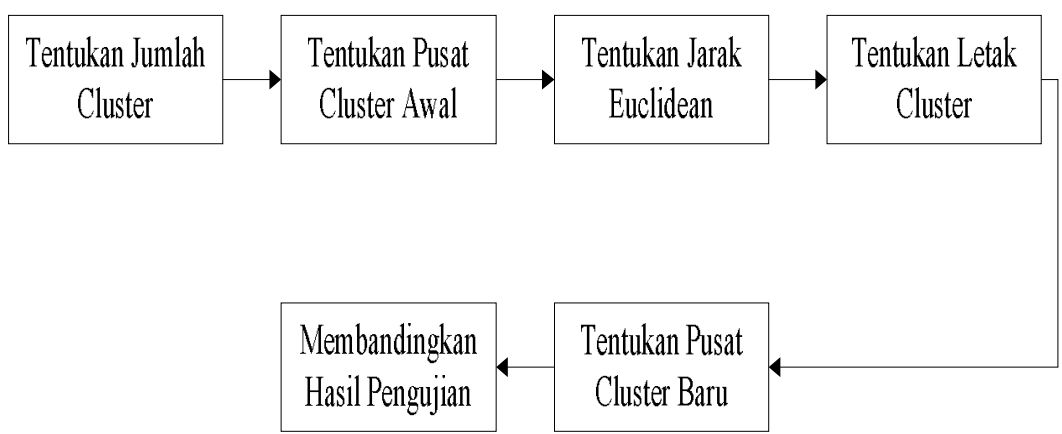

Gambar 2. Pemprosesan K-Means Clustering

\subsection{Analisis Data}

Tahapan ini adalah tahapan pembersihan data. Data yang didapat dari Dinas Kesehatan Jawa Barat di bersihkan sehingga tidak terdapat ada data yang sama atau duplikasi. Kemudian setelah data di bersihkan lalu data tersebut di sajikan menggunakan Software Microsoft Office Excel 2016.

\subsection{Data Set}

Data set adalah data yang sudah dibersihkan pada tahapan sebelumnya. Adapun bentuk data set ini dapat dilihat pada tabel 1 dibawah ini. 
Tabel 1. Dataset

\begin{tabular}{lrrrr}
\hline Kota/Kabupaten & Terkonfirmasi & Isolasi & Sembuh & Meninggal \\
\hline Kab. Bogor & 4.325 & 19 & 4.29 & 16 \\
\hline Kab. Sukabumi & 2.421 & 348 & 2.039 & 34 \\
\hline Kab. Cianjur & 209 & 0 & 207 & 2 \\
\hline Kab. Bandung & 5.617 & 1.616 & 3.974 & 27 \\
\hline Kab. Garut & 3.791 & 1.061 & 2.669 & 61 \\
\hline Kab. Tasikmalaya & 328 & 3 & 323 & 2 \\
\hline Kab. Ciamis & 1.415 & 609 & 777 & 29 \\
\hline Kab. Kuningan & 1.936 & 338 & 1.582 & 16 \\
\hline Kab. Cirebon & 2.807 & 439 & 2.293 & 75 \\
\hline Kab. Majalengka & 1.514 & 209 & 1.275 & 30 \\
\hline Kab. Sumedang & 1.241 & 217 & 991 & 33 \\
\hline Kab. Indramayu & 790 & 2 & 778 & 10 \\
\hline Kab. Subang & 1.153 & 443 & 696 & 14 \\
\hline Kab. Purwakarta & 1.761 & 93 & 1.615 & 53 \\
\hline Kab. Karawang & 7.679 & 1.385 & 6.147 & 147 \\
\hline Kab. Bekasi & 10.73 & 2.082 & 8.589 & 59 \\
\hline Kab. Bandung Barat & 1.972 & 515 & 1.436 & 21 \\
\hline Kab. Pangandaran & 135 & 0 & 134 & 1 \\
\hline Kota Bogor & 3.627 & 5 & 3.58 & 42 \\
\hline Kota Sukabumi & 1.748 & 812 & 926 & 10 \\
\hline Kota Bandung & 7.568 & 1.144 & 6.335 & 89 \\
\hline Kota Cirebon & 585 & 3 & 564 & 18 \\
\hline Kota Bekasi & 17.904 & 3.335 & 14.397 & 172 \\
\hline Kota Depok & 21.399 & 4.226 & 16.897 & 276 \\
\hline Kota Cimahi & 3.147 & 331 & 2.771 & 45 \\
\hline Kota Tasikmalaya & 2.554 & 497 & 2.037 & 20 \\
\hline Kota Banjar & 450 & 125 & 301 & 24 \\
\hline Kun & $5 a$ & \\
\hline
\end{tabular}

Sumber: Dinas Kesehatan Provinsi Jawa Barat Pada Tahun 2021

\subsection{Analisis Cluster}

Analisis cluster merupakan sebuah cara untuk menganalisa data dan mengelompokan objek kedalam kelas yang sama, sehingga objek yang berada dikelas yang sama memiliki kesamaan atau kemiripan data.

\subsection{Jumlah Kelompok (Cluster)}

Pada jumlah cluster atau kelompok ini peneliti membagi data yang didapat dari dinas terkait kedalam 3 kelompok atau cluster. Adapun kelompok yang dimaksud seperti dibawah ini:

a. Kelompk $\mathrm{C} 0$ adalah penuluran rendah.

b. Kelompok $\mathrm{C} 1$ adalah penuluran sedang.

c. Kelompok $\mathrm{C} 3$ adalah penuluran tinggi. 


\subsection{Menentukan Centroid Awal.}

Dalam algoritma $K$-Means Clustering untuk memulai sebuah perhitungan maka harus ditentukan terebih dahulu nilai centroid awal. Centroid awal dapat di pilih secara acak dari kumpulan data set yang dimiliki. Adapun centroid awal yang dijadikan pada perhitungan ini adalah seperti tabel 2 dibawah ini:

Tabel 2. Centroid Awal

\begin{tabular}{lrrrr}
\hline Kota/Kabupaten & Terkonfirmasi & Isolasi & Sembuh & Meninggal \\
\hline Kab. Bogor & 4.325 & 19 & 4.29 & 16 \\
\hline Kota Bandung & 7.568 & 1.144 & 6.335 & 89 \\
\hline Kota Bekasi & 17.904 & 3.335 & 14.397 & 172 \\
\hline
\end{tabular}

\subsection{Algoritma K-Means Clusterng}

Seperti yang telah dijelaskan sebelumnya bahwa penelitian ini menggunakan algoritma $K$-Means Clustering dan tools yang di gunakan adalah rapidminer studio 7.6. Berikut ini adalah proses pengolahan data dengan rapidminer menggunakan algoritma $K$-Means Clustering:

\subsubsection{Menjalankan Aplikasi Rapidminer}

Pada bagian pertama, peneliti membuka dan menjalankan aplikasi rapidminer. Adapaun tampilan dari halaman awal adalah seperti berikut ini:

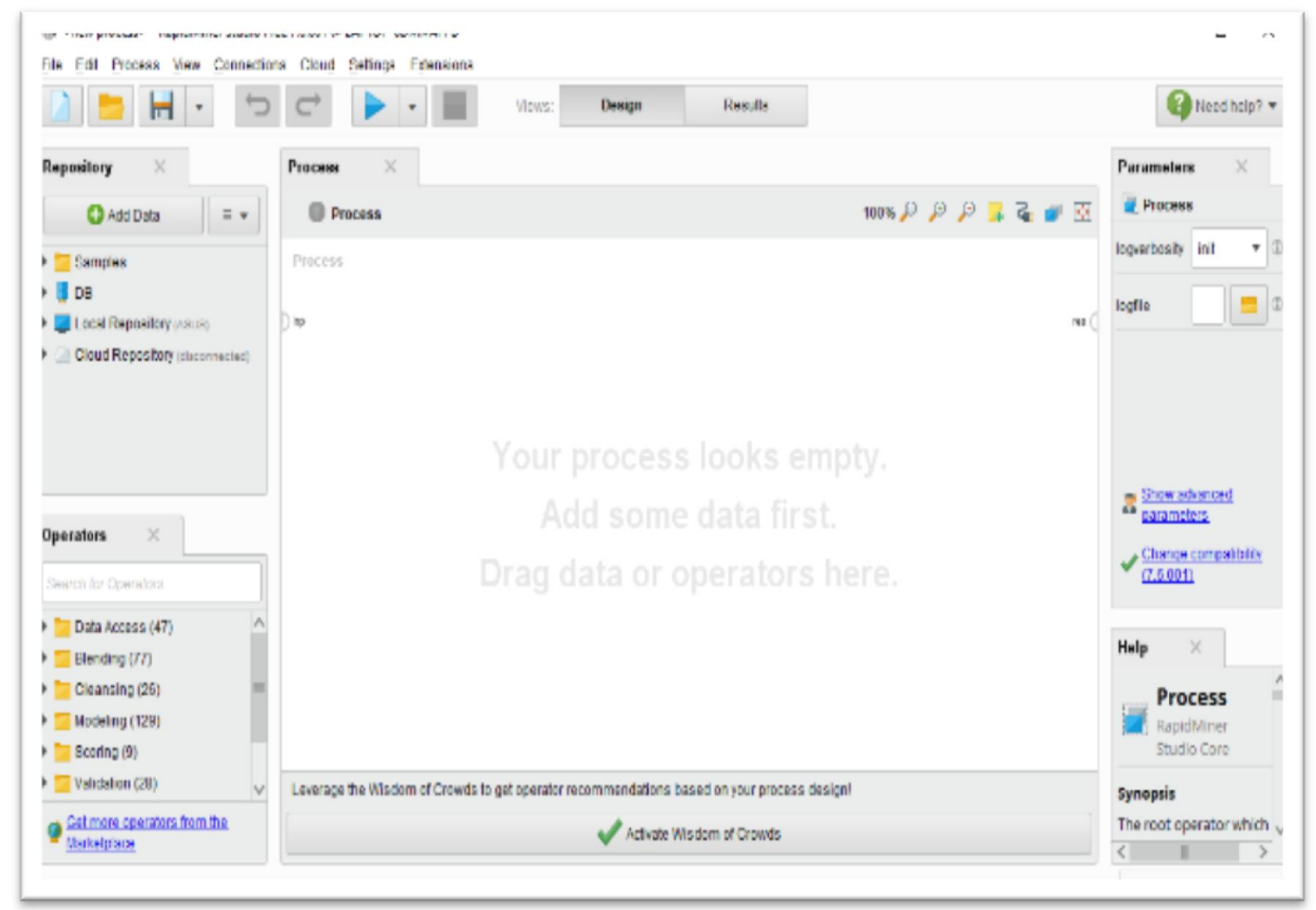

Gambar 3. Halaman Awal Rapidminer 


\subsubsection{Input Data Set}

Setelah aplikasi Rapidminer Studio 7.6 dibuka, maka langkah selanjutnya ialah menginputkan data set yang sudah disiapkan sebelumnya. Data set yang diinputkan berformat Microsoft Office Exel. Untuk memasukan data set ke dalam aplikasi rapidminer bisa menggunakan operator yang sudah di sediakan yaitu salah satunya read excel. Adapun bentuk dari proses input data set seperti yang ada pada gambar dibawah ini:

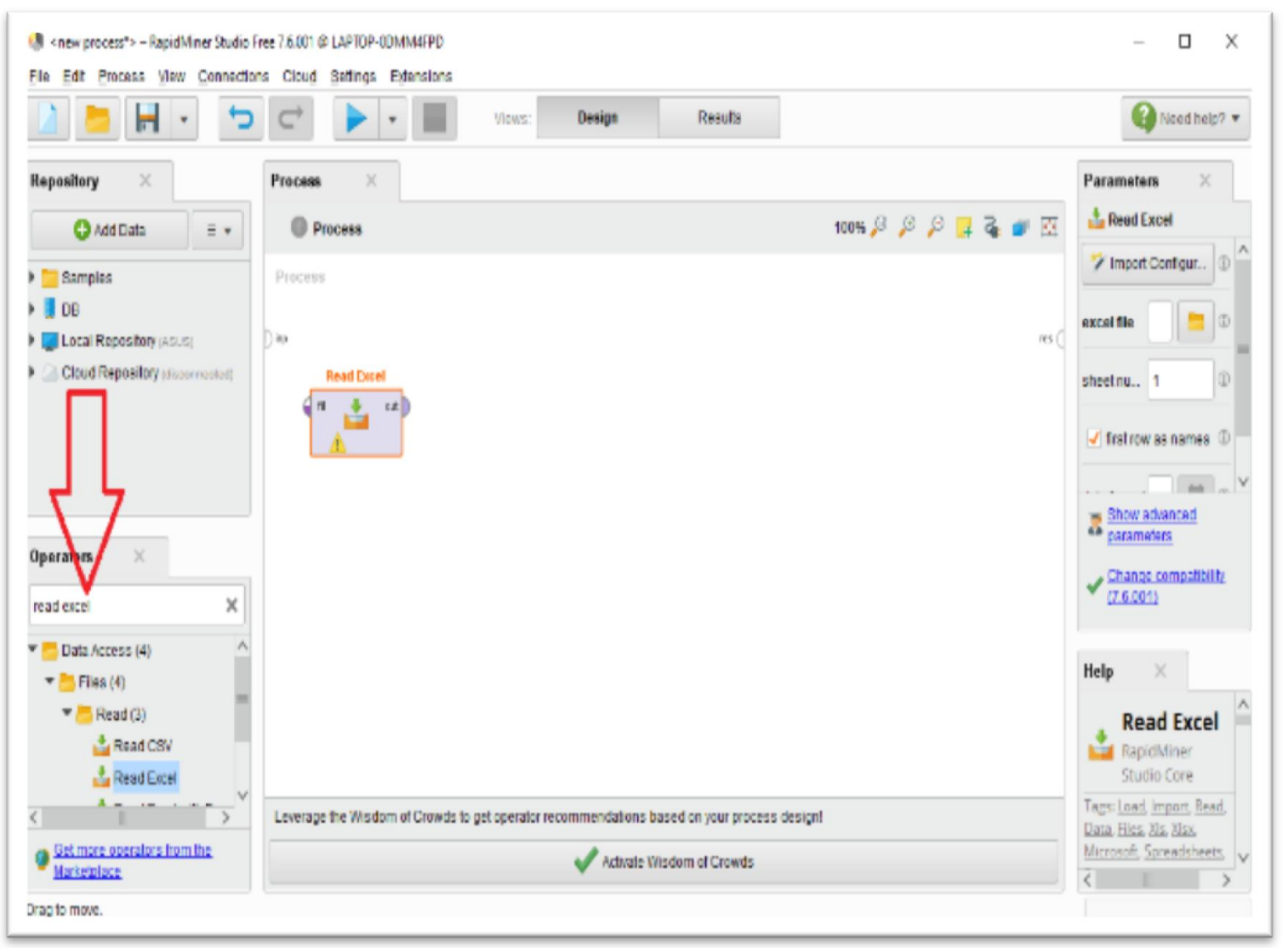

Gambar 4. Input Data Set

\subsubsection{Proses Perhitungan K-Means Clustering}

Setelah data set berhasil di inputkan kedalam aplikasi rapidminer menggunakan operator read excel, maka selanjutnya adalah melakukan pengolahan data set menggunakan operator yang sudah disediakan yaitu clustering. Adapun proses pengolahan dataset menggunakan algoritma $K$-Means Clustering dapat dilihat pada gamabr berikut ini: 


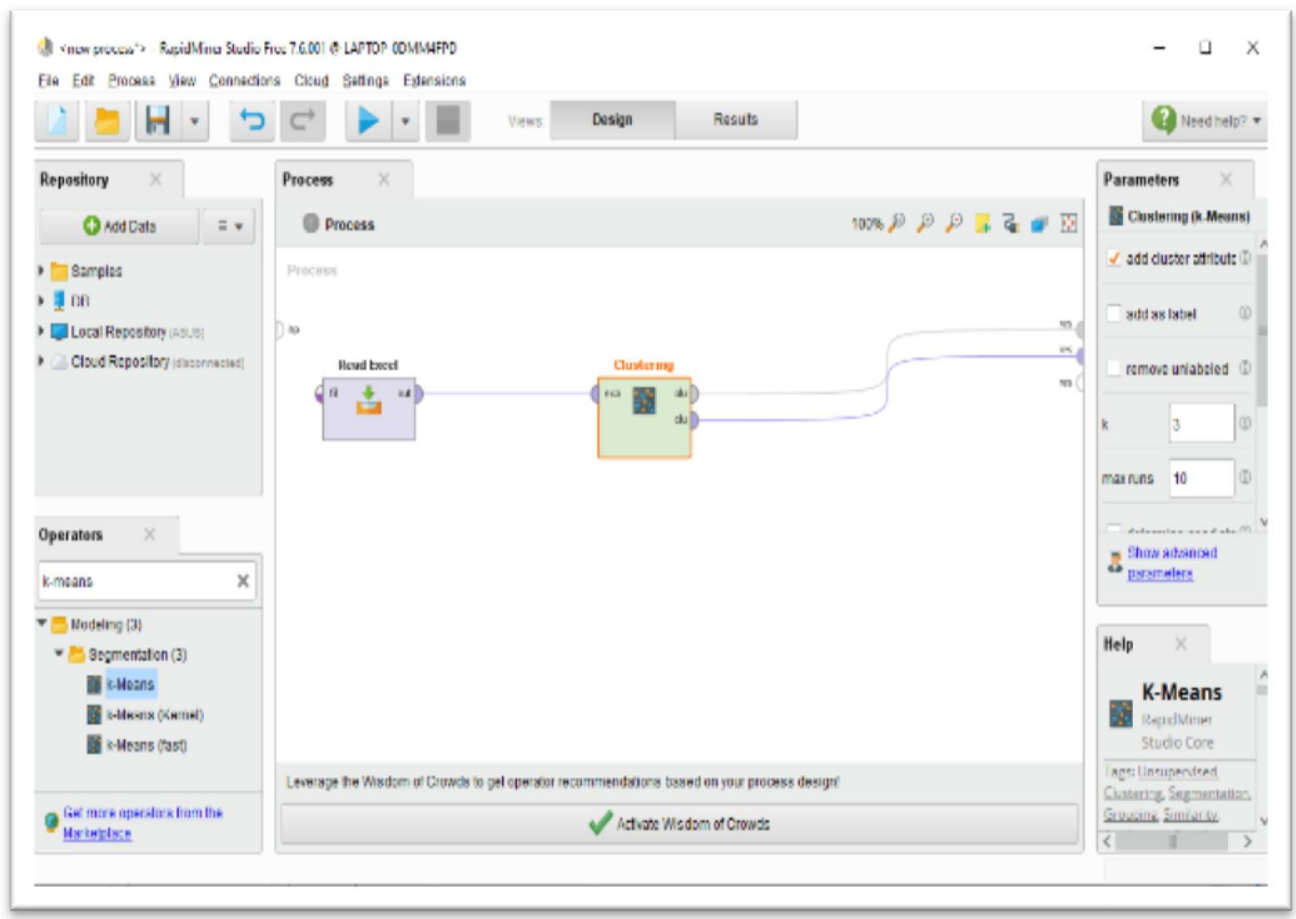

\subsubsection{Hasil Clustering}

Gambar 5. Proses Clustering Data set

Sesudah melakukan pengolahan data pesebaran virus corona di jawa barat menggunakan aplikasi rapidminer, maka didapatkan hasil dari pengolahan data ini seperti gambar dibawah ini:

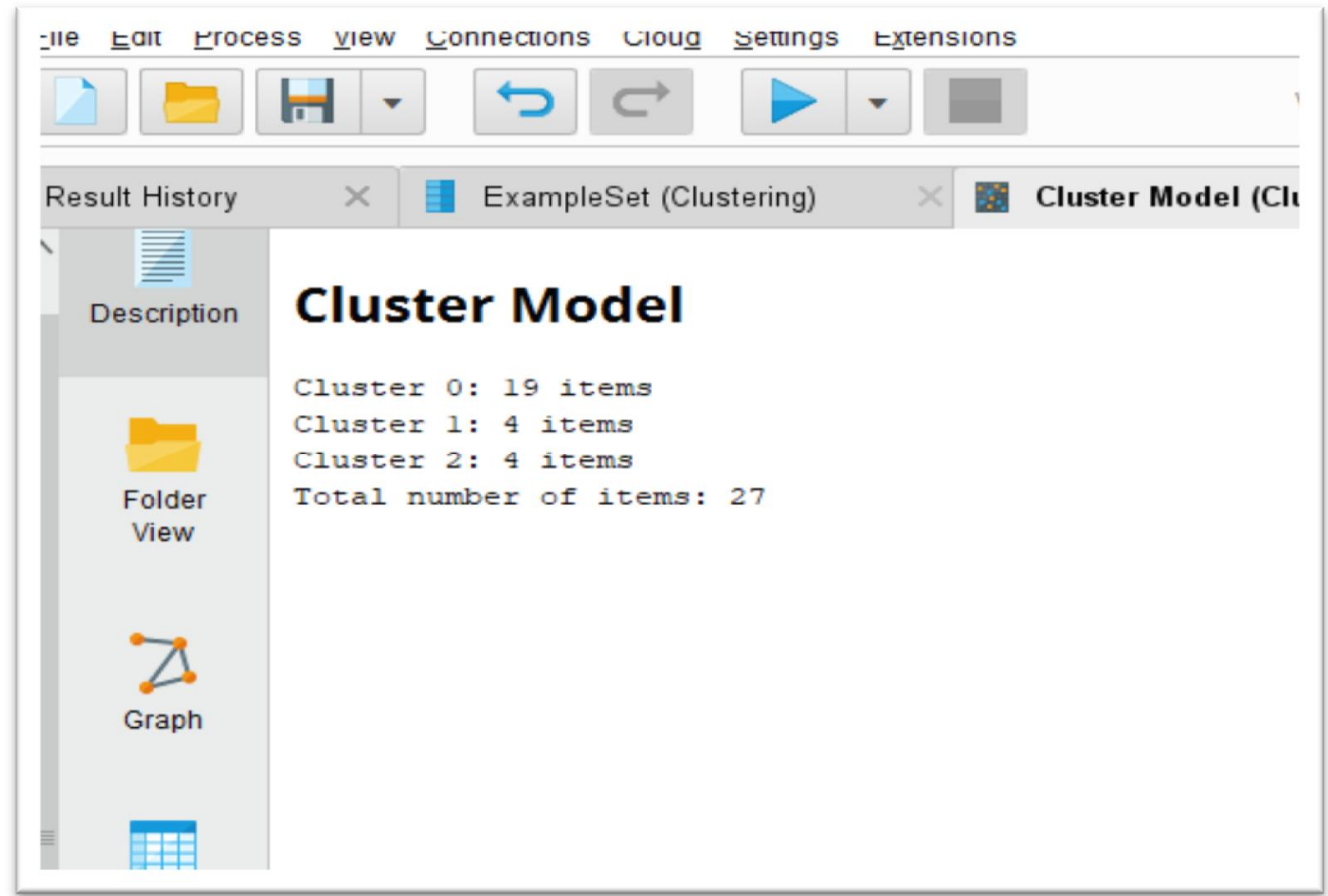

Gambar 6. Hasil Clustering Data Set 


\subsubsection{Hasil Analisa}

Setelah melakukan pengolahan data menggunakan aplikasi rapidminer menggunakan algoritma $K$-Means Clustering, Maka didapat hasil dari pengolahan dataset seperti tabel 3, 4 dan 5 dibawah ini:

Tabel 3. Hasil Analisa Kategori Rendah (C0)

\begin{tabular}{lrrrr}
\hline Kabupaten/Kota & Terkonfirmasi & Isolasi & Sembuh & Meninggal \\
\hline Kab. Bogor & 4.325 & 19 & 4.29 & 16 \\
\hline Kab. Sukabumi & 2.421 & 348 & 2.039 & 34 \\
\hline Kab. Cianjur & 209 & 0 & 207 & 2 \\
\hline Kab. Bandung & 5.617 & 1.616 & 3.974 & 27 \\
\hline Kab. Garut & 3.791 & 1.061 & 2.669 & 61 \\
\hline Kab. Kuningan & 1.936 & 338 & 1.582 & 16 \\
\hline Kab. Cirebon & 2.807 & 439 & 2.293 & 75 \\
\hline Kab. Majalengka & 1.514 & 209 & 1.275 & 30 \\
\hline Kab. Purwakarta & 1.761 & 93 & 1.615 & 53 \\
\hline Kab. Karawang & 7.679 & 1.385 & 6.147 & 147 \\
\hline Kab. Bekasi & 10.73 & 2.082 & 8.589 & 59 \\
\hline Kab. Bandung Barat & 1.972 & 515 & 1.436 & 21 \\
\hline Kab. Pangandaran & 135 & 0 & 134 & 1 \\
\hline Kota Bogor & 3.627 & 5 & 3.58 & 42 \\
\hline Kota Bandung & 7.568 & 1.144 & 6.335 & 89 \\
\hline Kota Bekasi & 17.904 & 3.335 & 14.397 & 172 \\
\hline Kota Depok & 21.399 & 4.226 & 16.897 & 276 \\
\hline Kota Cimahi & 3.147 & 331 & 2.771 & 45 \\
\hline Kota Tasikmalaya & 2.554 & 497 & 2.037 & 20 \\
\hline & & & &
\end{tabular}

Tabel 4. Hasil analisa kategori sedang (C1)

\begin{tabular}{lrrrr}
\hline Kabupaten/Kota & Terkonfirmasi & Isolasi & Sembuh & Meninggal \\
\hline Kab. Ciamis & 1.415 & 609 & 777 & 29 \\
\hline Kab. Sumedang & 1.241 & 217 & 991 & 33 \\
\hline Kab. Subang & 1.153 & 443 & 696 & 14 \\
\hline Kota Sukabumi & 1.748 & 812 & 926 & 10 \\
\hline
\end{tabular}

Tabel 5. Hasil analisa kategori tinggi (C2)

\begin{tabular}{lrrrr}
\hline Kabupaten/Kota & Terkonfirmasi & Isolasi & Sembuh & Meninggal \\
\hline Kab. Tasikmalaya & 328 & 3 & 323 & 2 \\
\hline Kab. Indramayu & 790 & 2 & 778 & 10 \\
\hline Kota Cirebon & 585 & 3 & 564 & 18 \\
\hline Kota Banjar & 450 & 125 & 301 & 24 \\
\hline
\end{tabular}




\section{KESIMPULAN}

Setelah melakukan tahapan demi tahapan seperti yang telah dijabarkan diatas, maka dapat ditarik kesimpulan pada penelitian ini yaitu; Peneliti membagi kelompok atau cluster pada penelitian ini menjadi 3 kelompok yang terdiri dari rendah $(\mathrm{C} 0)$, sedang $(\mathrm{C} 1)$ dan tinggi $(\mathrm{C} 2)$. Dataset yang digunakan pada penelitian ini adalah sebanyak 27 data, ini sesuai dengan jumlah kabupaten/kota yang ada didaerah Jawa Barat saat ini. Dari hasi penelitian diketahui bahwa tingkat pesebaran penuluran yang masuk kedalam C0 adalah sebanyak 19, C1 sebanyak 4 dan C2 sebanyak 4 kabupaten/kota. Hasil dari penelitian ini tentunya bisa dijadikan oleh pihak terkait dalam upaya pengambilan keputusan dalam menekan laju penuluran virus corona di daerah jawa barat.

\section{SARAN SARAN}

Saran saran yang bisa peneliti harapkan untuk penelitian kedepannya adalah seperti berikut ini:

1. Peneliti menyarankan supaya dilaksanakan pengembangan oleh penelitian selanjutnya menggunakan aplikasi dan algoritma yang berbeda didalam teknik data mining.

2. Hasil dari penelitian ini bisa di jadikan bahan pertimbangan bagi dinas kesehatan dan pemerintahan Jawa Barat dalam upaya melakukan tindakan tindakan pencegahan penularan virus corona di daerah tersebut.

\section{UCAPAN TERIMA KASIH}

Peneliti mengucapkan ribuan terimakasih kepada semua pihak yang telah terlibat didalam penelitian ini.

\section{DAFTAR PUSTAKA.}

[1] Z. Zaharah and G. I. Kirilova, "Impact of Corona Virus Outbreak Towards Teaching and Learning Activities in Indonesia," SALAM J. Sos. dan Budaya Syar-i, Vol. 7, No. 3, 2020, doi: 10.15408/sjsbs.v7i3.15104.

[2] T. N. Darmansah, Putra, I. Chairuddin, S. Informasi, S. Tinggi, T. Pekanbaru, and S. Informasi, "Design of The Sirp to Record Community Travels During The Pandemi Period (Case Study: Kecamatan IV Koto Aur Malintang),” Vol. 8, No. 2, 2021.

[3] G. D. Rembulan, T. Wijaya, D. Palullungan, K. N. Alfina, and M. Qurthuby, "Kebijakan Pemerintah Mengenai Coronavirus Disease (COVID-19) di Setiap Provinsi di Indonesia Berdasarkan Analisis Klaster,” JIEMS (Journal Ind. Eng. Manag. Syst., Vol. 13, No. 2, 2020, doi: 10.30813/jiems.v13i2.2280.

[4] American Journal of Sociology, "Sosialisasi tentang Pencegahan Covid-19 di Kalangan Siswa Sekolah Dasar di SD Minggiran 2 Kecamatan Papar Kabupaten Kediri," J. Chem. Inf. Model., Vol. 53, No. 9, pp. 1689-1699, 2019.

[5] N. R. Yunus and A. Rezki, "Kebijakan Pemberlakuan Lock Down Sebagai Antisipasi Penyebaran Corona Virus Covid-19," SALAM J. Sos. dan Budaya Syar-i, Vol. 7, No. 3, 
pp. 227-238, 2020, doi: 10.15408/sjsbs.v7i3.15083.

[6] K. D. R Sianipar, S. Wanti Siahaan, M. Siregar, and P. R. Fikrul Ilmi Zer, "Penerapan Algoritma K-Means Dalam Menentukan Tingkat Kepuasan Pembelajaran Online pada Masa Pandemi Covid-19,” J. Teknol. Inf., Vol. 4, No. 1, pp. 101-105, 2020.

[7] T. H. Siagian, "Corona Dengan Discourse Network Analysis," J. Kebijak. Kesehat. Indones., Vol. 09, No. 02, pp. 98-106, 2020.

[8] D. Darmansah, "Analisa Penyebab Kerusakan Tanaman Cabai Menggunakan Metode K-Means, ” JATISI (Jurnal Tek. Inform. dan Sist. Informasi), Vol. 7, No. 2, pp. 126-134, 2020, doi: 10.35957/jatisi.v7i2.309.

[9] C. S. Journal, R. Ordila, R. Wahyuni, Y. Irawan, and M. Y. Sari, "Penerapan Data Mining Untuk Pengelompokan Data Rekam Medis Pasien Berdasarkan Jenis Penyakit Dengan Algoritma Clustering (Studi Kasus: Poli Klinik PT . Inecda),” Vol. 9, No. 2, pp. 148-153, 2020.

[10] F. Wulandari and P. A. Jusia, "Klasifikasi Data Mining Untuk Mendiagnosa Penyakit ISPA Menggunakan Metode Nä̈ve Bayes pada Puskesmas Jambi Selatan,” Vol. 2, No. 3, pp. 214-227, 2020.

[11] Y. Darnita, R. Toyib, and Y. Kurniawan, "Penerapan Metode K-Means Clustering pada Aplikasi Android pada Tanaman,” Vol. VII, No. September, pp. 105-114, 2020.

[12] S. A. Rahmah, "Klasterisasi Pola Penjualan Pestisida Menggunakan Metode K-Means Clustering (Studi Kasus di Toko Juanda Tani Kecamatan Hutabayu Raja)," Vol. 1, No. 1 , pp. 1-5, 2020.

[13] B. Nepal, M. Yamaha, H. Sahashi, and A. Yokoe, "Analysis of Building Electricity Use Pattern Using K-Means Clustering Algorithm by Determination of Better Initial Centroids and Number of Clusters," Energies, Vol. 12, No. 12, 2019, doi: 10.3390/en12122451.

[14] R. A. Indraputra and R. Fitriana, “K-Means Clustering Data COVID-19,” Vol. 10, No. 3, pp. 275-282, 2020.

[15] I. U. 2019 Yusli Yenni, "Indonesian Journal of Computer Science," STMIK Indones. Padang, Vol. 8, No. 2, p. 121, 2019.

[16] R. Rusnandi, S. Suparni, and A. B. Pohan, "Penerapan Data Mining Untuk Analisis Market Basket Dengan Algoritma Fp-Growth pada PD Pasar Tohaga," J. Nas. Pendidik. Tek. Inform., Vol. 9, No. 1, p. 119, 2020, doi: 10.23887/janapati.v9i1.19349.

[17] K. Khomsatun, D. Ikhsan, M. Ali, and K. Kursini, "Sistem Pengambilan Keputusan Pemilihan Lahan Tanam di Kabupaten Wonosobo Dengan K-Means Clustering dan Topsis," J. Nas. Pendidik. Tek. Inform., Vol. 9, No. 1, p. 55, 2020, doi: 10.23887/janapati.v9i1.23073. 
[18] N. W. Darmansah, Wardani and K. Selatan, "Analisis Pesebaran Penularan Virus Corona di Provinsi Jawa Tengah Menggunakan Metode K-Means Clustering," Vol. 8, No. 1, 2021. 